\title{
РУССКОЕ НАСЕЛЕНИЕ БЛИЖНЕГО ЗАРУБЕЖЬЯ: ГЕОДЕМОГРАФИЧЕСКАЯ ДИНАМИКА ПОСТСОВЕТСКОГО ПЕРИОДА
}

\section{СЕРГЕЙ СУЩИЙ}

\begin{abstract}
В статье рассматривается геодемографическая динамика русского населения ближнего зарубежья 8 постсоветский период. Анализируются его количественные изменения, трансформация системы расселения, уровня урбанизированности, половозрастной структуры. Исследование показало, что в постсоветский период произошло значительное сокращение численности русских во всех странах ближнего зарубежья. Наиболее интенсивно данный проиесс шел в 1990-е годы. Максимальные демографические потери в этот период понесло русское население Закавказья и ряда стран Средней Азии. В начале XXI века темпы и абсолютные масштабы сокращения снижаются, но сам тренд остается устойчивым и представляет результируюшую естественной убыли русского населения, его миграции в Россию и дальнее зарубежье, ассимилячии со стороны титульньх народов. Соотнотение данных факторов убыли менялось во времени и по отдельным странам. Почти во всех русских общинах ближнего зарубежья фиксируется ощутимый перевес женщин, который продолжает увеличиваться. Медианный возраст русских в половине стран данной группы достигает 45-50 лет. Уровень урбанизированности большинства русских общин снизился за счет опережающей убыли нестоличных горожан. Лучше сохранилось столичное и сельское русское население. Изменилось демографическое соотношение отдельных стран и макрорегионов ближнего зарубежья. Численность русских Казахстана и Украинь (без народных республик Донбасса) уже является сопоставимой, а в странах Балтии русских осталось больше, чем в Средней Азии. Повышенной демографической устойчивостью характеризуется русское население непризнанных (частично признанных) государств, возникших и существующих при поддержке России.
\end{abstract}

Ключевые слова: ближнее зарубежье, русское население, геодемографическая динамика, половозрастная структура, уровень урбанизации, миграция, ассимиляция.

\section{ВВЕДЕНИЕ И ПОСТАНОВКА ПРОБЛЕМЫ}

Согласно последней советской переписи населения (декабрь 1989 г.) численность русских в союзных республиках СССР составляла 25,3 млн человек (Всесоюзная перепись... 1989). Таким образом, распад Советского Союза на 15 государств и появление ближнего зарубежья привели к одной из самых масштабных трансформаций в государственнополитической системе расселения русского народа за его историю. Почти $20 \%$ от общей численности русских оказалось за пределами своего государства ${ }^{1}$.

СЕРГЕЙ ЯкОВЛЕВИЧ СУЩИЙ (SS7707@mail.ru), ФЕДЕРАЛЬНЫЙ ИССЛЕДОВАТЕЛЬСКИЙ ЦЕНТР ЮЖНЫЙ НАУчНЫЙ ЦЕНТР РАН, РОССИЯ.

СТАТЬЯ ПОДГОТОВЛЕНА В РАМКАХ ГОСУДАРСТВЕННОГО ЗАДАНИЯ ЮЖНОГО НАУЧНОГО ЦЕНТРА РАН: МЕЖДИСЦИПЛИНАРНЫЙ ПРОЕКТ №02-20-МД «РУССКИЙ НАРОД В ПЕРВОЙ ПОЛОВИНЕ XXI В. ГЕОДЕМОГРАФИЧЕСКИЕ РЕАЛИИ И ПЕРСПЕКТИВЫ»; ТЕМА № 0256-2019-0О45 «КОНКУРЕНТНОЕ, УСТОЙЧИВОЕ И СБАЛАНСИРОВАННОЕ РАЗВИТИЕ ЮЖНОГО МАКРОРЕГИОНА: ВЕКТОРЫ СОЦИАЛЬНО-ЭКОНОМИЧЕСКОЙ МОДЕРНИЗАЦИИ И ДЕМОГРАФИЧЕСКОЙ ДИНАМИКИ».

СТАТЬЯ ПОСТУПИЛА В РЕДАКЦИЮ В АПРЕЛЕ 2020 Г.

1 Для подавляющей части русского населения не только союзных республик, но и РСФСР “своим” государством был именно СССР. 
С момента появления ближнего зарубежья его русское население стало заметно влиять на количественную динамику всего русского народа. Существенную роль русские общины играли и в этнодемографических процессах новых постсоветских государств. В Казахстане, Латвии и Эстонии в начале 1990-х годов на русских приходилось соответственно 37, 33 и 30\% населения, еще в двух странах (Украина и Киргизия) они составляли более $1 / 5$ жителей. Во всех этих странах русские, по сути, являлись вторым по численности народом.

В ближнем зарубежье можно выделить несколько макрорегионов, историческая, социокультурная, социально-экономическая специфика которых определяла многие значимые геодемографические показатели местного русского населения (в том числе общую его численность, территориальную распространенность и формы расселения, уровень межнациональной брачности). Северо-западный макрорегион включает страны Балтии, западный - Украину, Белоруссию, Молдавию. Третий регион составляют государства Закавказья, четвертый - Центральной Азии (Казахстан и страны Средней Азии). Но следует отметить, что самые общие тенденции геодемографической динамики русского населения в постсоветский период совпадали для всех макрорегионов постсоветского пространства.

\section{ОБЗОР ИССЛЕДОВАНИЙ И ИНФОРМАЦИОННАЯ БАЗА}

Демографическая динамика русского населения ближнего зарубежья, его миграционная активность и включенность в ассимиляционные процессы привлекали внимание многих исследователей (Кабузан 1996; Рыбаковский 1996; Савоскул 2001). Немало работ посвящено русским отдельных стран и макрорегионов Украины и Молдавии (Митрофанова, Сущий 2017; Остапенко, Субботина 2011; Романцов 2008), Балтии (Волков 2013; Манаков, Чученкова 2016; Манаков 2020; Марцинкявичус 2013; Никифиров, Полещук 2013; Сущий 2018а; Халлик 2011), Закавказья (Мосаки 2018; Цуциев 2006; Юнусов $^{2}$ ), Казахстана и Средней Азии (Алейников, Боровиков 2013; Сущий 2018b; Тишков 1993; Федорко, Курбанов 2018; Хоперская 2012).

Вместе с тем в большинстве перечисленных работ непосредственно геодемографические аспекты жизнедеятельности русских общин постсоветского пространства находятся на периферии исследовательского интереса. Еще существенней то, что обнаруживается ощутимый дефицит общих работ, посвященных количественной, пространственной, расселенческой динамике русского населения всего ближнего зарубежья; сдвигам в удельном соотношении его ведущих общин.

Информационные источники исследования - материалы переписи населения СССР 1989 г. (Всесоюзная перепись... 1989); итоги постсоветских переписей, размещенные на сайтах государственных статистических комитетов стран ближнего зарубежья.

\footnotetext{
2 Юнусов А.С. (2003). Этнические и миграционные процессы в постсоветском Азербайджане. URL: http://chairs.stavsu.ru/geo/Conference/c1-67.htm
} 
Часть данных статистических материалов была собрана на сайте «Population statistics of Eastern Europe and the former USSR $»^{3}$.

Следует учитывать, что страны постсоветского пространства различаются как числом переписей, так и сроками их проведения (таблица 1). И требуется экспертная доработка этой статистической информации для сведения ее в общую картину геодемографической динамики русского населения в пределах бывшего СССР. Осложняет такой анализ то, что Украина, на которую на рубеже 1990-х годов приходилось 46\% русских ближнего зарубежья, ограничилась переписью 2001 г., результаты которой к настоящему времени существенно устарели. А Узбекистан, обладатель крупнейшей русской общины в Средней Азии, в постсоветский период вообще обошелся без переписей ${ }^{4}$. Крайне ограниченной является и этнодемографическая статистика по Туркмении (результаты переписи 1995 г. существенно завышены (Жуков, Резникова 2001: 31-47), а переписи 2012 г. не опубликованы).

Таблица 1. Переписи населения в странах ближнего зарубежья, 1990-2010-е годы

\begin{tabular}{|c|c|c|c|c|c|c|c|c|c|c|c|c|c|}
\hline Территория & ฉ̊ & ब่ & 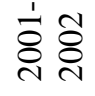 & $\stackrel{\text { }}{8}$ & ঠ্ণ & ஜ & $\stackrel{8}{8}$ & $\stackrel{\circ}{\circ}$ & 공 & 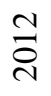 & $\stackrel{ \pm}{\stackrel{্}{~}}$ & 吕 & 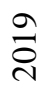 \\
\hline Азербайджан & & $*$ & & & & & $*$ & & & & & & $*$ \\
\hline Белоруссия & & $*$ & & & & & $*$ & & & & & & $*$ \\
\hline Грузия & & & $*$ & & & & & & & & $*$ & & \\
\hline Украина & & & $*$ & & & & & & & & & & \\
\hline \multicolumn{14}{|l|}{ Узбекистан } \\
\hline Таджикистан & & $*$ & & & & & & $*$ & & & & & \\
\hline Туркменистан & $*$ & & & & & & & & & $*$ & & & \\
\hline Казахстан & & $*$ & & & & & $*$ & & & & & & \\
\hline Киргизия & & $*$ & & & & & $*$ & & & & & & \\
\hline Армения & & & $*$ & & & & & & $*$ & & & & \\
\hline Литва & & & $*$ & & & & & & $*$ & & & & \\
\hline Латвия & & $*$ & & & & & & & $*$ & & & & \\
\hline Эстония & & $*$ & & & & & & & $*$ & & & & \\
\hline Молдавия & & & & & $*$ & & & & & & $*$ & & \\
\hline \multicolumn{14}{|c|}{ Непризнанные и частично признанные государства ближнего зарубежья } \\
\hline Абхазия & & & & $*$ & & & & & $*$ & & & & \\
\hline Нагорный Карабах & & & & & & $*$ & & & & & & * & \\
\hline Приднестровье & & & & & $*$ & & & & & & & $*$ & \\
\hline Южная Осетия & & & & & & & & & & & & * & \\
\hline Донецкая народная республика & & & $*$ & & & & & & & & & & $*$ \\
\hline Луганская народная республика & & & $*$ & & & & & & & & & & $*$ \\
\hline
\end{tabular}

Примечание: Перепись населения на территории будущих народных республиках Восточного Донбасса (Донеикой и Луганской) проводилась в 2001 г., когда они еще находились в составе Украины.

Остальные страны ближнего зарубежья в постсоветский период провели по две переписи ${ }^{5}$ большинство которых пришлось на два временных интервала - 1999-2002

\footnotetext{
${ }^{3}$ URL: http://pop-stat.mashke.org

${ }^{4}$ Для него имеются данные текущего демографического учета, которые, однако, предполагают серьезную экспертную проработку.

5 За исключением Азербайджана и Белоруссии, в которых прошли уже три переписи, но результаты последней (2019 г.) пока не опубликованы.
} 
и 2009-2011 гг., что позволяет в первом приближении отследить динамику их русского населения в 1990-е и 2000-е годы. Анализ этого процесса в 2010-е годы является значительно более сложной задачей. Данные текущего демографического учета для 20172019 гг. имеются только по четырем странам (Эстония, Латвия, Казахстан, Киргизия). Еще в трех (Литва, Грузия, Молдавия) соответствующая информация по русскому населению имеется на середину 2010-х годов. Для четырех стран (Армения, Азербайджан, Белоруссия, Таджикистан) экспертная оценка динамики их русских общин, по необходимости, опирается на геодемографические тренды 1990-2000-х годов.

Дополнительным обстоятельством, требовавшим учета, являлось политическое дробление постсоветского пространства, появление в ближнем зарубежье ряда непризнанных (частично признанных) государств, также проводивших переписи своего населения. В настоящее время данная группа насчитывает шесть «политий», две из которых (народные республики Донбасса) возникли всего несколько лет назад и до середины 2010-х годов. являлись региональными сообществами Украины. Наконец, на общем демографическом потенциале русского ближнего зарубежья и долевом соотношении его крупных макрорегионов сказалось включение в состав Российской Федерации (март 2014 г.) Крымского полуострова, сократившее русскую общину Украины на 1,5 млн человек.

Следует отметить, что ограниченный формат журнальной публикации предполагает концентрацию только на центральных тенденциях и аспектах анализируемых процессов и явлений.

\section{ОБЩАЯ ГЕОДЕМОГРАФИЧЕСКАЯ ДИНАМИКА}

Несмотря на существенные социально-политические, экономические, социокультурные различия между странами ближнего зарубежья, динамика их русского населения обнаруживает множество сходных черт. Прежде всего, совпадал центральный геодемографический тренд: все русские общины количественно сокращались, данное сокращение сохранялось на всем протяжении постсоветского периода. Оно было повсеместным и в территориальном разрезе: захватывало все регионы и все уровни системы расселения от столиц до глубокой сельской периферии.

Общим было и то, что естественная убыль в данном процессе почти всегда играла подчиненную роль. Центральное место, различаясь по временным периодам, макрорегионам и странам, принадлежало миграции, ассимиляции и различным формам смены этнической самоидентификации у части местного русского населения - прежде всего у людей «смешанного» происхождения (биэтнофоров), один из родителей которых был русским, а второй - представителем титульного народа ${ }^{6}$.

\footnotetext{
${ }^{6}$ Отчасти такая смена могла представлять социальную мимикрию, выбор более конъюнктурно выгодного в новых условиях варианта национальной принадлежности. Но нередко со временем происходила и реальная трансформация идентичности биэтнофора.
} 
1990-e годы. В целом за 1990-е годы численность русских ближнего зарубежья сократилась почти на $30 \%$ (с 25,3 до 17,8 млн человек). Минимальными в долевом отношении оказались количественные потери русского населения Белоруссии (14,9\%), а также Латвии и Эстонии (22-26\%). Несколько больше (27-28\%) потеряли крупнейшие русские общины Украины и Казахстана. Но в абсолютных цифрах именно на эти две страны пришлось основная количественная убыль русских ближнего зарубежья (соответственно 3,0 и 1,75 млн человек; таблица 2).

Таблица 2. Численность русского населения в ближнем зарубежье, тыс.

\begin{tabular}{|c|c|c|c|c|c|c|}
\hline $\begin{array}{ll}\text { Государства } & \text { Годы } \\
\end{array}$ & 1989 & $\begin{array}{l}1999- \\
2002\end{array}$ & $\begin{array}{c}2003- \\
2005 \\
\end{array}$ & $\begin{array}{c}2009- \\
2011\end{array}$ & $\begin{array}{c}2014- \\
2015 \\
\end{array}$ & \begin{tabular}{|c|}
$2018-$ \\
2019
\end{tabular} \\
\hline Украина** & 11360 & 8330 & & $6500-7500 *$ & & $3300-3800 *$ \\
\hline Белоруссия & 1342 & 1142 & & 785 & & $590-650 *$ \\
\hline Узбекистан & 1653 & $1000-1050 *$ & & $600-650 *$ & & $500-550 *$ \\
\hline Таджикистан & 388 & 68 & & 35 & & $25-30 *$ \\
\hline Туркмения & 334 & $190-200^{*}$ & & $90-100^{*}$ & & $60-75^{*}$ \\
\hline Казахстан & 6228 & 4480 & & 3794 & & 3553 \\
\hline Киргизия & 917 & 603 & & 408 & & 353 \\
\hline Грузия*** & 262 & 67,6 & & $35-38 *$ & \multirow[t]{3}{*}{26,4} & $20-21 *$ \\
\hline Азербайджан $* * * *$ & 390 & 142 & & 119 & & $75-90 *$ \\
\hline Армения & 52 & 15 & & 12 & & 9-10* \\
\hline Литва & 344 & 220 & & 175 & \multirow[t]{3}{*}{138} & $120-130 *$ \\
\hline Латвия & 906 & 703 & & 556 & & 487 \\
\hline Эстония & 475 & 351 & & 341 & & 329 \\
\hline Молдавия ***** & 351 & $215-220 *$ & 201 & $155-165^{*}$ & 112 & $90-100 *$ \\
\hline \multicolumn{7}{|c|}{ Непризнанные (и частично признанные) государства } \\
\hline Абхазия & 75 & $25-27^{*}$ & 23,4 & $22-23 *$ & 22,3 & $21-22 *$ \\
\hline Южная Осетия & 2,1 & $0,7-0,8 *$ & & $0,5^{*}$ & 0,6 & $0,6^{*}$ \\
\hline Нагорный Карабах & 1,9 & $0,2 *$ & 0,17 & $0,2 *$ & 0,24 & $0,23-0,24 *$ \\
\hline $\begin{array}{l}\text { Приднестровская } \\
\text { Молдавская республика }\end{array}$ & \multirow[t]{2}{*}{211} & \multirow[t]{2}{*}{$187-190 *$} & \multirow[t]{2}{*}{185} & \multirow[t]{2}{*}{$165-170 *$} & \multirow[t]{2}{*}{160} & $158-160 *$ \\
\hline $\begin{array}{l}\text { Донецкая и Луганская } \\
\text { народные республики }\end{array}$ & & & & & & $1100-1300$ \\
\hline $\begin{array}{l}\text { Все ближнее зарубежье, } \\
\text { млн человек }\end{array}$ & 25,29 & $17,74-17,81 *$ & & $13,85-14,93 *$ & & $10,79-11,64^{*}$ \\
\hline
\end{tabular}

Источник: Составлено по (Всесоюзная перепись... 1989); Population statistics of Eastern Europe and the former USSR. URL: http://pop-stat.mashke.org (дата обращения 17.03.2020); данным национальных переписей и расчетам автора.

Примечания: *-Оценка автора; ** - для 2018-2019 г2. без Крыма и народных республик Донбасса; *** - без Абхазии и Южной Осетии; **** - без Нагорного Карабаха; ***** - без Приднестровья.

Ускоренные темпы убыли демонстрировали государства Закавказья. Русские общины этих стран в первое постсоветское десятилетие сократились в 2,8-3,5 раза. Но максимально в данный период на постсоветском пространстве в процентном отношении сократилось русское население Таджикистана (в 5,7 раза), хотя и в остальных странах Центральной Азии убыль оказалась весьма ощутимой (30-50\%).

Структура демографических потерь русских общин существенно различалась по макрорегионам и временным интервалам. Только в первой половине 1990-х годов для всего ближнего зарубежья было характерно известное единообразие: центральную роль играл отток в Россию его наиболее «россиецентричного» и мало адаптированного к местной 
жизни русского населения. Но уже в середине 1990-х годов структура убыли в отдельных странах приобретает все более ощутимую специфику.

В западном макрорегионе (Украина, Белоруссия, Молдавия) центральную роль начинает играть смена идентичности многочисленного русско-титульного населения, в советский период самоопределявшегося в качестве русских, а в новых социальнополитических и социокультурных условиях выбиравшего титульную идентичность. В середине 1990-х годов 20\% русских Украины имели мать-украинку, 10\% - отца-украинца (Савоскул 2001: 89), т. е. около 30\% русского населения страны являлись этническими «полуукраинцами». В целом русско-украинские биэтнофоры в данное время составляли около 20\% населения Украины. Сменой идентичности части представителей этой обширной группы в значительной степени определялась динамика русского населения Украины: его убыль в 1990-е годы в размере 2 млн человек была связана с данным фактором (еще 1 млн составили естественные потери и миграционный отток) (Митрофанова, Сущий 2017: 48).

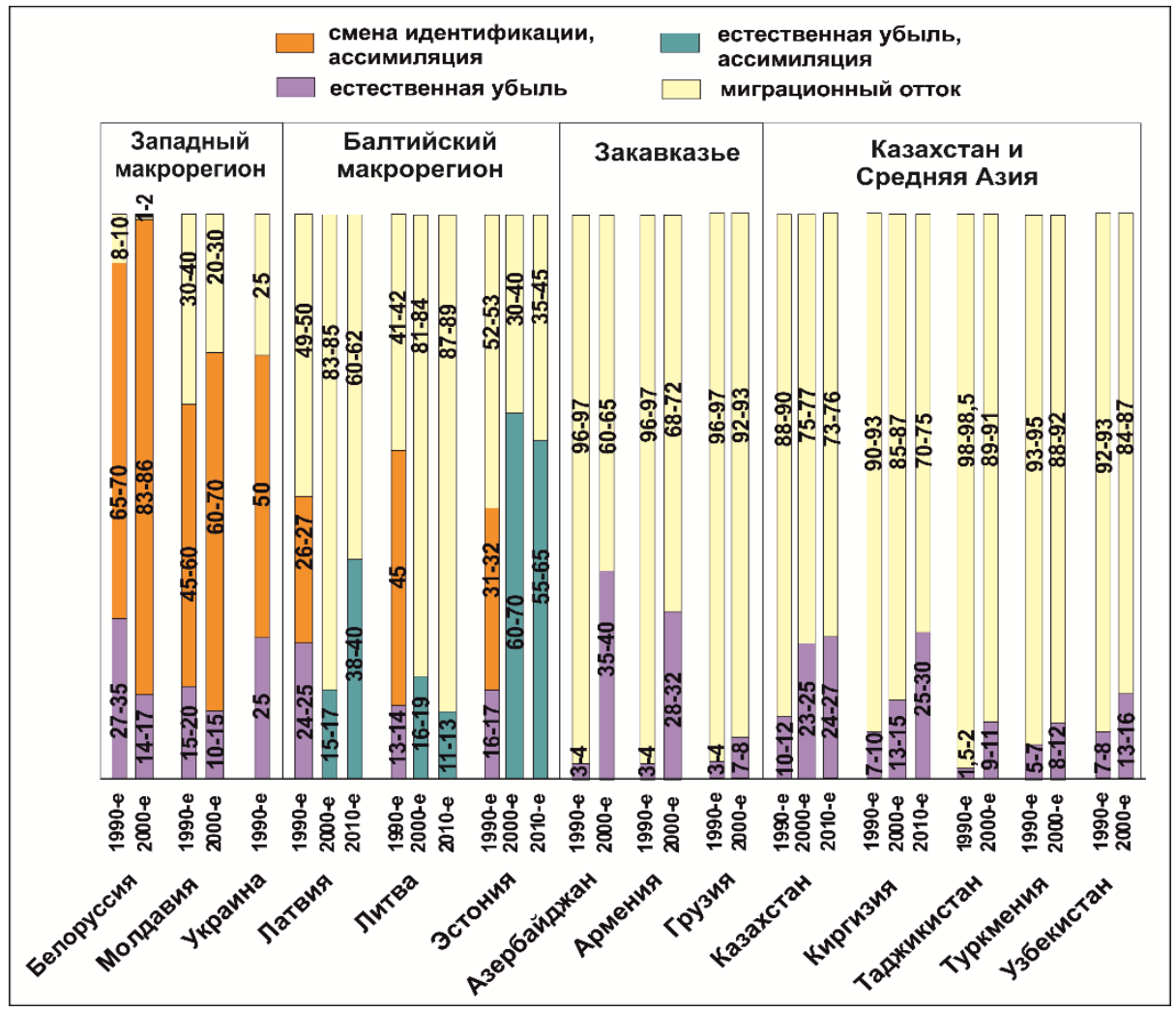

Рисунок 1. Компоненты демографической убыли русских ближнего зарубежья, 19902010-е годы, \% ${ }^{7}$

Источник: Составлено по (Всесоюзная перепись... 1989); Population statistics of Eastern Europe and the former USSR. URL: http://pop-stat.mashke.org (дата обращения 17.03.2020); данным национальных переписей и расчетам автора.

7 Для рисунков 1-3 данные по Молдавии даны без районов, вошедших в состав Приднестровской Молдавской республики; по Грузии - без территории Абхазии и Южной Осетии, по Азербайджану - без территории Нагорного Карабаха. 
Аналогичным было положение в двух других странах западного макрорегиона. В последние советские десятилетия 70-75\% русских БССР вступали в межэтнические браки; для Молдавской ССР данный показатель составлял 57-62\% (Население СССР 1989: 230-231, 282-283). Как результат, уже в 1990-е годы у русских женщин Молдавии 7 из 10 детей рождались от отца другой национальности (Остапенко, Субботина 2011: 63-65). При этом основными брачными партнерами русских в этих странах были представители титульных народов, что существенно ускоряло ассимиляцию смешанного потомства межнациональных семей. В целом во всех трех странах западного макрорегиона порядка 2/3 зафиксированной в 1990-е годы убыли русского населения было связано со сменой идентичности и ассимиляцией молодого поколения смешанных семей (рисунок 1).

В менее значительных масштабах процесс смены идентичности русско-титульных биэтнофоров фиксируется во второй половине 1990-х годов в странах Балтии (Сущий 2018a). В 1970-1980-е годы у русского населения прибалтийских республик СССР также были широко распространены межнациональные браки (выбирали супруга другой национальности 25-29\% русских Эстонии, 35-38\% - Латвии и 47-57\% русских Литвы) (Население СССР 1989: 276-277, 286-287, 318-319). Но, в отличие от западного макрорегиона, основными брачными партнерами русских в Прибалтике были представители русскоязычных общин (прежде всего украинцы и белорусы). Доля русскотитульных браков оставалась ограниченной, хотя постепенно росла. Но в новых социальнополитических условиях более привлекательными оказывались не только титульные, но и другие европейские идентичности (польская, немецкая и др.), в которых также теперь предпочитала самоопределяться часть смешанного населения, ранее идентифицировавшего себя как русское. В общей сложности на смену идентичности в 1990-е годы могло приходиться порядка 30-46\% зафиксированной в странах Балтии количественной убыли русских (Сущий 2018а: 24).

Порядка 40-50\% зафиксированного в 1990-е годы сокращения русского населения северо-западного макрорегиона было связано с миграцией. Однако отток в Россию в качестве значительного фактора демографической динамики русских стран Балтии ограничился только 1992-1994 гг. (соответственно 64,6; 36,0 и 20,1 тыс. человек в год) (Савоскул 2001: 285). Уже во второй половине 1990-х годов среднегодовой чистый отток упал до 12-13 тыс. человек. Столько же в целом приходилось и на возросшую к этому времени естественную убыль, которая в Эстонии поднялась до 6\%о в год, в Латвии составляла 7,5\% (Бузаев 2016). В двух южных макрорегионах ближнего зарубежья в первое постсоветское десятилетие убыль русского населения была связана почти исключительно с его оттоком: по отдельным странам 88-97\% сокращения приходилось на миграцию ${ }^{8}$

Ассимиляционная составляющая демографической динамики русских в государствах Закавказья была минимальной вследствие незначительного числа русскотитульных биэтнофоров. К тому же в данной группе абсолютно доминировало потомство межнациональных семей, представленных «титульным» отцом и русской матерью. А такие

\footnotetext{
${ }^{8}$ Нетто-миграция русских из стран СНГ и Балтии, 1992-2001 гг. URL: http://allrefs.net/c4/4e7nk/p11/ (дата обращения 17.03.2020).
} 
биэтнофоры в значительном большинстве уже в советское время выбирали титульную идентичность.

Иной была ситуация в Центральной Азии, в ряде стран которой ассимиляционная динамика скорее способствовала пополнению русских общин в связи с обрусением части представителей крупных русскоязычных диаспор, прежде всего украинской, белорусской, немецкой. Этот процесс фиксировался уже в 1960-1970-е годы, но заметно ускорился в постсоветский период после того, как наиболее национально-ориентированные представители данных общин вернулись на историческую родину и в странах макрорегиона сохранилась их русифицированная часть, при этом значительно сжатая в размерах. Для этого в массе русскоязычного и «русскокультурного» населения самым распространенным (при этом вполне психологически и социокультурно приемлемым) вариантом оказывался выбор русского супруга с последующим обрусением общего потомства (Сущий 2018b: 26-27).

Таким образом, в странах макрорегиона, в которых русские составляли заметную часть населения (прежде всего в Казахстане, Киргизии, отчасти в Узбекистане), русские общины, по сути, превратились во второй (наряду с титульными народами) полюс этнической консолидации, притягивающий представителей русскоязычных диаспор, этногенетически и социокультурно не имевших отношения к Центральной Азии.

2000-e годbl. Сформированные в 1990-е годы тренды демографической динамики русских ближнего зарубежья перешли в XXI век. Для всех русских общин были характерны достаточно значительные естественные потери, которые дополнялись миграционной убылью. Но социально-экономическая стабилизация постсоветского пространства, рост доходов и уровня жизни значительной части населения отразились на масштабах оттока русских - они существенно упали. Работало на сокращение миграции и то, что основная масса русских, однозначно настроенных на отъезд, к этому времени уже покинула ближнее зарубежье. Остались те, кто так или иначе сумел адаптироваться к постсоветским реалиям, в том числе к известным статусным потерям и очевидному доминированию титульных наций во всех престижных социальных иерархиях. Как результат, темпы убыли русского населения в 2000-е годы снизились в 9 из 12 стран ближнего зарубежья, по которым был возможен достаточно достоверный анализ 9 .

Общая численность русских в данной группе стран сократилась в этом десятилетии на 2,8-2,9 млн человек. Как и в 1990-е годы, основная убыль пришлась на две крупнейшие общины: русских Украины и Казахстана (соответственно 1,0-1,8 и 0,65 млн человек) ${ }^{10}$. Значительные количественные потери (порядка 400-450 тыс. человек) могло понести русское население Узбекистана, сократившись к 2010 г. до 500-700 тыс. (Арефьев 2012:

\footnotetext{
${ }^{9}$ Впрочем, даже замедлившись, эти темпы оставались достаточно высокими, в большинстве стран ближнего зарубежья составляя 1,6-2,2\% в год.

${ }^{10}$ Напомним, что данные по Украине являются расчетной оценкой, поскольку после 2001 г. переписи населения в стране не проводились.
} 
121; Хоперская 2012: 2). Более чем на 350 тыс. снизилось число русских в Белоруссии, в пределах 150-200 тыс. потеряли русские общины Латвии и Киргизии ${ }^{11}$.

Определенным образом трансформировался и состав группы стран - антилидеров по темпам демографической убыли русских. В ней сохранились Грузия, Таджикистан, появились Туркмения и Узбекистан (таблица 3). Во всех этих странах русские общины потеряли в 2000-е годы порядка 40-50\% своей численности. Минимальные темпы потерь в первом десятилетии XXI века продемонстрировало русское население Эстонии (2,8\%) и Казахстана $(15,3 \%)$.

Таблица 3. Сокращение численности русского населения в странах ближнего зарубежья, 1989-2019 гг., \%

\begin{tabular}{|c|c|c|c|}
\hline Страна & 1989-1999/2002 & 1999/2002-2009/2011 & $2009 / 2011-2018 / 2019$ \\
\hline Украина & 26,7 & $10-22 *$ & $49-50 *(14-20) * *$ \\
\hline Белоруссия & 14,9 & 31,3 & $17,2-24,8^{*}$ \\
\hline Узбекистан & $36,5-39,5^{*}$ & $38-40 *$ & $15,4-16,7 *$ \\
\hline Таджикистан & 82,5 & 48,5 & $14,3-28,6^{*}$ \\
\hline Туркмения & $40-43 *$ & $50-52,5^{*}$ & $25-33 *$ \\
\hline Казахстан & 28,1 & 15,3 & 6,4 \\
\hline Киргизия & 34,2 & 32,3 & 13,5 \\
\hline Грузия & 74,2 & $44-48 *$ & $43-45^{*}$ \\
\hline Азербайджан & 63,6 & 16,2 & $24,5-37 *$ \\
\hline Армения & 71,2 & 20,0 & $17-25^{*}$ \\
\hline Литва & 36,0 & 20,5 & $26-31 *$ \\
\hline Латвия & 22,4 & 20,9 & 12,4 \\
\hline Эстония & 26,1 & 2,8 & 3,5 \\
\hline Молдавия & $37,3-38,7$ & $25-28^{*}$ & $39,4-42 *$ \\
\hline \multicolumn{4}{|c|}{ Непризнанные (и частично признанные) государства } \\
\hline Абхазия & $64-66,7$ & $12,0-14,8$ & $4,3-8,7$ \\
\hline Южная Осетия & $61,9-66,7$ & $28,6-37,5$ & 20,0 \\
\hline Нагорный Карабах & 89,5 & 0,0 & $15-20$ \\
\hline $\begin{array}{l}\text { Приднестровская } \\
\text { Молдавская республика }\end{array}$ & 11,4 & $10,5-11,8$ & $4,2-5,9$ \\
\hline Все ближнее зарубежье & $29,6-29,9 *$ & $17,4-22,0 *$ & $\begin{array}{r}20,8-22 * \\
(10,5-11)^{* *}\end{array}$ \\
\hline
\end{tabular}

Источник: Составлено по (Всесоюзная перепись... 1989); Population statistics of Eastern Europe and the former USSR. URL: http://pop-stat.mashke.org (дата обращения 17.03.2020); данным национальных переписей и расчетам автора.

Примечания: * - Оченка автора; ** - в скобках дан показатель убыли без учета Крыма и Севастополя.

Для всего русского зарубежья сокращение численности русского населения составило в 2000-е годы 17,4-22\%. Это было значительно ниже уровня первого постсоветского десятилетия. К началу второго десятилетия XXI века общая численность русских в данной группе стран составляла порядка 13,8-14,9 млн.

Структура демографических потерь русских общин, как и в 1990-е годы, отличалось заметной спецификой для различных макрорегионов и отдельных стран.

\footnotetext{
${ }^{11}$ Рассчитано по Population statistics of Eastern Europe and the former USSR. URL: http://pop-stat.mashke.org (дата обращения 17.03.2020).
} 
Сокращение численности русского населения стран Балтии (прежде всего Литвы и Латвии) определялось высокой естественной убылью (7-8\%о в год) и миграцией, основным направлением которой, однако, являлась уже не Россия, а другие страны Евросоюза (Сущий 2018a: 25).

В западном макрорегионе масштабы оттока русского населения в 2000-е годы были незначительны. И его демографические потери определялись в основном естественной убылью и ассимиляцией все более многочисленного потомства смешанных семей. К этому времени уже 3/4 браков, заключаемых русскими Молдавии, были межэтническими (Остапенко, Субботина 2011: 65). Среди русских Белоруссии русско-титульные биэтнофоры могли составлять порядка 45-50\%, среди русского населения Украины - 43 45\% (Митрофанова, Сущий 2017: 52). В результате порядка 65-85\% потерь русского населения западного макрорегиона могло приходиться на ассимиляционную составляющую. Причем, в Белоруссии темпы демографический убыли выросли по сравнению с 1990-ми годами более, чем в 2 раза.

В двух южных макрорегионах основной причиной сокращения русских общин в первом десятилетии XXI века оставалась миграция. Расчеты показывают, что с ней было связано порядка 60-70\% убыли русского населения Армении и Азербайджана, более 90\% потерь русской общины Грузии. В Центральной Азии на отток могло приходиться 75-77\% сокращения русского населения Казахстана, 84-88\% - Киргизии и Узбекистана, около 90\% -Таджикистана.

2010-e zоды. Анализ геодемографических трендов 2010-х годов, как уже отмечалось, серьезно затруднен фрагментарностью имеющейся информации. Крайне сложной является экспертная оценка современной численности русского населения Украины. Размеры убыли, связанные с переходом Крымского полуострова в состав Российской Федерации, известны. Но только в самом первом приближении просчитываемы этнодемографические последствия затяжного военного конфликта на востоке страны, появления народных республик Донбасса, разнонаправленной миграции и резкой активизации ассимиляционных процессов по обе стороны от границы, разделившей ДНР-ЛНР и остальную Украину.

В первом приближении представляется возможным оценить численность русских современной Украины (без народных республик Донбасса) в 3,3-3,8 млн человек, что несколько меньше итогов ранее выполненного расчета (Митрофанова, Сущий 2017: 55). Данная величина уже сопоставима с численностью русского населения Казахстана, составлявшей, по данным текущего учета, в начале 2019 г. 3,53 млн. Следует отметить, что хотя абсолютные масштабы демографической убыли русских Казахстана в 2010-е годы были весьма значительными (241 тыс. человек за 2009-2019 гг.), в процентном отношении $(6,4 \%)$ эта убыль была почти минимальной в пределах ближнего зарубежья. Меньше потеряла только русская община Эстонии (3,5\%). Еще в двух странах (Латвия и Киргизия) относительные потери русского населения в 2010-е годы составили соответственно 12,4 и 13,5\%, еще в 6 -находились в диапазоне 17-30\%. Максимальное сокращение продемонстрировали русские общины Грузии и Молдавии (в пределах 39$45 \%)$. 
Учитывая, что естественная убыль русских ближнего зарубежья за этот десятилетний период, в зависимости от страны, составляла от 1,5\% (Казахстан) до 7-8\% (Литва, Латвия), демографические потери русских общин практически на всем постсоветском пространстве в 2010-е годы по-прежнему в самой значительной степени определялись другими причинами. Для государств Балтии, как и в 2000-е годы, это был отток в более развитые и успешные страны Евросоюза, хотя в Литве и Латвии постепенно возрастало и значение фактора ассимиляции смешанного потомства русско-титульных семей, общее число которых заметно увеличилось в начале XXI века. Так, из почти 5 тыс. детей, рожденных в 2015 г. в Латвии русскими матерями, только 60\% имели русского отца. У 26\% таких новорожденных отцом был латыш (Бузаев 2016: 26).

Для стран западного макрорегиона центральным фактором демографической убыли русского населения также являлись нарастающие темпы его смешения через межнациональную брачность с титульными народами с последующей ассимиляцией значительной части общего потомства (Остапенко, Субботина 2011: 65; Митрофанова, Сущий 2017: 49-50).

В Закавказье и Центральной Азии среди факторов сокращения численности русских продолжал доминировать миграционный отток, на который в большинстве стран этих двух макрорегионов приходилось 70-90\% убыли. Хотя в последние 5-10 лет в русских общинах, демонстрировавших в постсоветский период максимальное демографическое «сжатие» в силу серьезных половозрастных диспропорций, возрастающую роль в общей убыли начинает играть и естественно-воспроизводственный фактор.

Здесь следует учитывать общую кривую естественной динамики русских в постсоветский период, совпадавшую для России и ближнего зарубежья. После резкого ухода в зону убыли (1990-е годы) для всего русского населения было характерно постепенное улучшение показателей рождаемости и смертности, позволившее в первой половине 2010-х годов заметно сократить размеры естественных потерь на всем постсоветском пространстве. Но начиная с середины этого десятилетия, во всех странах данной группы у русских фиксируется новое падение рождаемости, связанное с входом во взрослую жизнь малочисленных поколений 1990-х годов. Соответственно, в 2016-2019 гг. пошли в «рост» и масштабы естественной убыли.

На 2018-2019 гг. общая численность русских ближнего зарубежья могла составлять порядка 10,7-11,6 млн, т. е. была на 3,1-3,3 млн меньше показателя рубежа 2000-2010 гг. Но почти половина этого сокращения (около 1,5 млн человек) была связана с переходом Крыма в состав Российской Федерации. То есть, непосредственно демографическими процессами обусловливалось 1,6-1,8 млн количественных потерь русских общин, что было в 2-2,5 раза меньше показателя 2000-х годов.

Основной причиной фиксируемого замедления убыли русских ближнего зарубежья является уже произошедшее их серьезное демографическое «сжатие». В целом за постсоветский период число русских сократилось в 2,2-2,4 раза (с 25,3 до 10,7-11,6 млн человек). Если в 1989 г. в союзных республиках СССР проживало 17,4\% русского населения страны, то к концу 2010-х годов на ближнее зарубежье России приходилось только 8,5-9\% русских, проживавших в пределах бывшего Советского Союза. 
В настоящее время 6-8\% русских от их численности на рубеже 1980-90-х годов остается в Грузии и Таджикистане, порядка 14-20\% - в Армении, Азербайджане, Туркмении. Только в трех государствах ближнего зарубежья (в Латвии, Эстонии, Казахстане) русские общины сумели сохранить более половины своего «советского» размера. Очевидным лидером здесь является Эстония (69\%) (без учета непризнанных и частично признанных государств, о которых будет сказано ниже; рисунок 2).

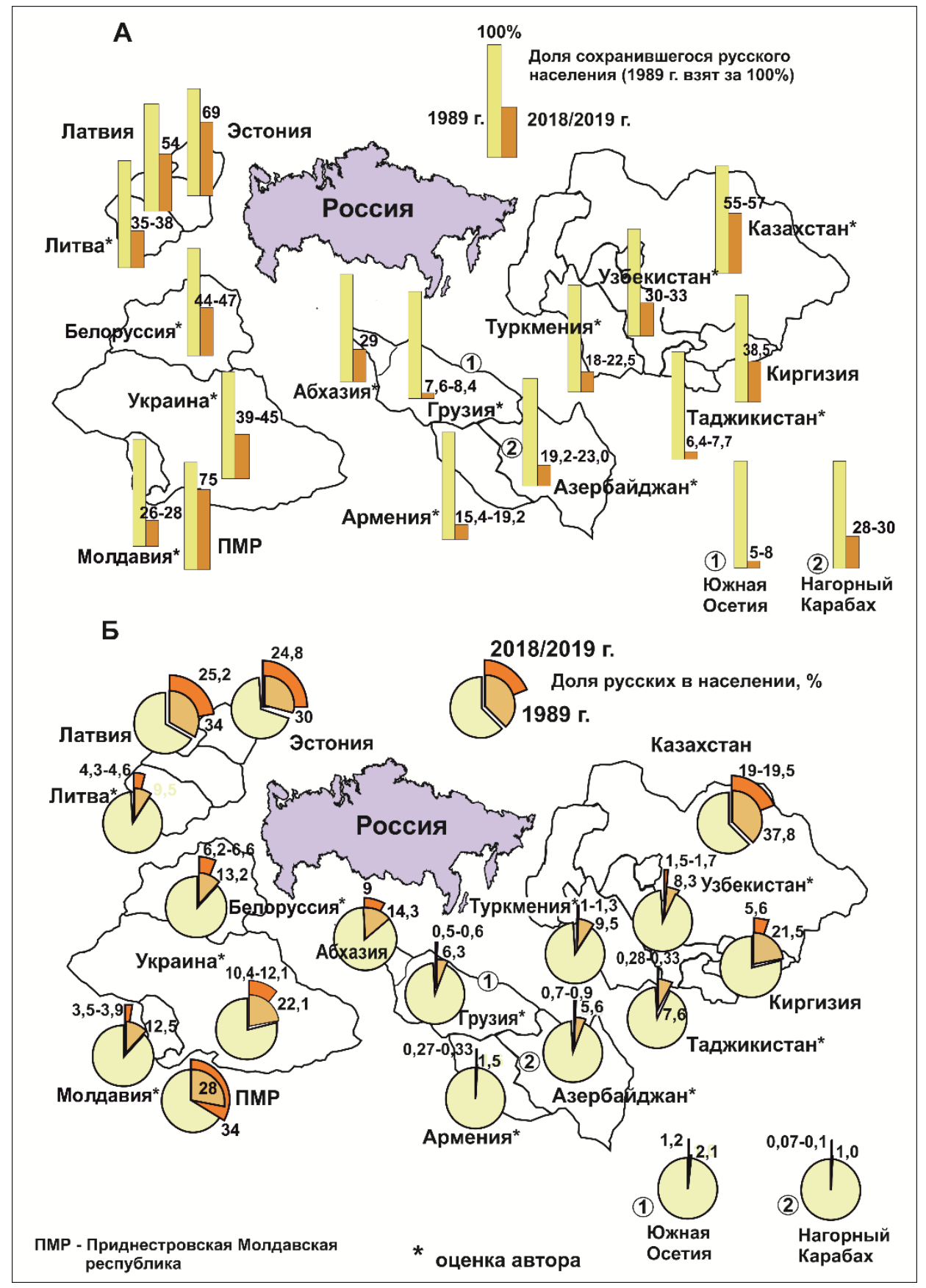

\section{Рисунок 2. Динамика русских общин стран ближнего зарубежья, 1989-2018/2019 гг.}

Источник: Составлено по (Всесоюзная перепись... 1989); Population statistics of Eastern Europe and the former USSR. URL: http://pop-stat.mashke.org (дата обращения 17.03.2020); данным национальных переписей и расчетам автора. 
Удельный вес русских в населении стран ближнего зарубежья также сокращался. Однако темпы этого сокращения определялись не только масштабами демографических потерь самих русских общин, но и динамикой всего населения каждого из постсоветских государств. Общая депопуляция стран Балтии и западного макрорегиона, а также Армении и Грузии снижала удельные потери местных русских. Ускоренный рост численности населения Азербайджана, Казахстана и Средней Азии эту удельную убыль заметно увеличивал. «Антирекордсменом» по этому показателю был Таджикистан, доля русских в котором за 1990-2010-е годы сократилась примерно в 25 раз. Но в несколько раз она упала и в остальных странах двух южных макрорегионов. Минимальными оказались долевые потери Эстонии и Латвии, в которых русские продолжают составлять около четверти населения.

\section{НЕПРИЗНАННЫЕ (ЧАСТИЧНО ПРИЗНАННЫЕ) ГОСУДАРСТВА}

Существенной спецификой отличалась геодемографическая динамика русского населения государственных образований, возникших в результате сецессии части территории из одной из стран ближнего зарубежья. В первой половине 1990-х годов на постсоветском пространстве возникло четыре таких государства (Нагорный Карабах, Абхазия, Южная Осетия, Приднестровье). В 2014 г. социально-политический кризис на Украине привел к появлению двух самопровозглашенных республик (Донецкой и Луганской). Для всех этих образований, за исключением Нагорного Карабаха, жизненно важное значение имела комплексная поддержка со стороны России. Превращение последней, по сути, в основного гаранта существования данных политий существенно сокращало темпы и абсолютные масштабы убыли русского населения.

Основные количественные потери последнего в Приднестровье, Абхазии и Южной Осетии пришлись на период активных боевых действий и связанного с войной глубокого социально-экономического кризиса (первая половина 1990-х годов). В дальнейшем масштабы демографической убыли русских существенно сокращались и были связаны в основном с отрицательной естественной динамикой, что обеспечивало существенно большую устойчивость русских общин, чем в странах, из которых данные политии выделились. К примеру, за 2002-2014 гг. численность русских в Грузии сократилась в 2,6 раза (с 67,6 до 26,4 тыс. человек), а в Абхазии за 2003-2016 гг. - только на $4,7 \%{ }^{12}$.

В Молдавии за 2004-2014 гг. русских стало меньше на 44,3\%; в Приднестровской республике за 2004-2012 гг. - на 13,6\%. Как результат, если в конце 1980-х годов численность русских Приднестровья составляла только $60 \%$ от русского населения остальной Молдавской ССР (соответственно 211 и 351 тыс. человек), то в середине 2010-х

12 Population statistics of Eastern Europe and the former USSR. URL: http://pop-stat.mashke.org (дата обращения 17.03.2020). 
годов соотношение уже стало обратным (160 тыс. русских в Приднестровье и только 112 тыс. - в Молдавии) ${ }^{13}$.

Этнополитическая и социокультурная динамика Украины и республик Донбасса во второй половине 2010-х годов свидетельствует о том, что аналогичном образом может количественно меняться в долгосрочной перспективе и их русское население (ускоренное сокращение на территориях, подконтрольных Киеву, и сохранение численности в пределах ДНР и ЛНР). При реализации такого сценария к 2040-2050 гг. число русских в народных республиках и на остальной Украине может стать сопоставимым, притом что в настоящее время ее русское население больше примерно в 3 раза (соответственно 3,3-3,8 и 1,1-1,3 млн человек) (Сущий 2016: 256-263).

Таким образом, именно социально-политическая ориентация постсоветских государств, уровень их системной «пророссийскости» являлись одним из центральных факторов, определявших количественную динамику местного русского населения.

Общая численность русских непризнанных (частично признанных) государств ближнего зарубежья до середины 2010-х годов оставалось незначительной (около 200 тыс. человек). Появление народных республик Донбасса увеличило это число до 1,3-1,5 млн. В настоящее время на данную группу стран приходится уже 12-13\% всего русского населения ближнего зарубежья. И сложившиеся на постсоветском пространстве этнодемографические тренды дают основания полагать, что их удельный показатель продолжит свой рост в будущем.

\section{УДЕЛЬНАЯ ДИНАМИКА РУССКИХ ПО СТРАНАМ И КРУПНЫМ МАКРОРЕГИОНАМ}

Крупнейшим средоточием русского населения в ближнем зарубежье на всем протяжении постсоветского периода оставалась Украина. Ее доля в общей численности русских на протяжении 1990-2000-х годов продолжала возрастать, постепенно приближаясь к 50\%. Но и к концу 2010-х годов, уже без Крыма, на нее могло приходиться порядка 41,2-43,8\% всех русских данной группы стран (4,4-5,1 млн человек). Однако следует учесть, что из этого числа порядка 1,1-1,3 млн составляло русское население народных республик Донбасса, без учета которого доля Украины снижалась до 31-32,5\% и уже, как отмечалось выше, была сопоставима с удельным показателем русской общины Казахстана.

В пределах современной Украины сохраняется несколько регионов, в которых русские не только многочисленны, но составляют заметную часть местного населения. В «украинской» части Донецкой области на них приходится 30-33\% жителей, в Харьковской и Запорожской - около четверти, в Одесской - до 20\%, в Днепропетровской - в пределах 16,5-17\% (Митрофанова, Сущий 2017: 52). Половина из десяти крупнейших

\footnotetext{
${ }^{13}$ Рассчитано по: (Всесоюзная перепись 1989); Population statistics of Eastern Europe and the former USSR. URL: http://pop-stat.mashke.org (дата обращения 17.03.2020).
} 
городских центров - средоточий русского населения ближнего зарубежья по-прежнему приходится на Украину (помимо Донецка это Харьков, Одесса, Киев, Днепропетровск).

Доля русской общины Белоруссии в структуре всего русского населения за 19902010-е годы могла несколько подрасти (с 5,3 до 5,5-5,6\%), а Молдавии, учтенной вместе с Приднестровьем, - остаться без изменения (2,2\%; рисунок 3$)$. Как результат, почти не изменился в постсоветский период и удельный вес всего западного макрорегиона, попрежнему составляющий около половины (49-51,7\%) русского населения ближнего зарубежья.

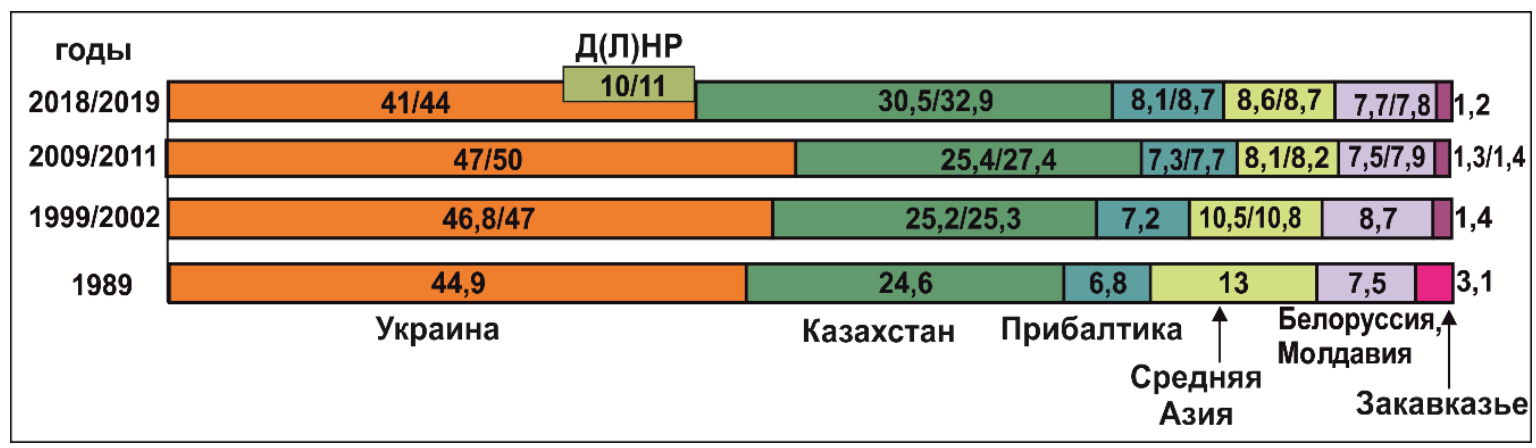

\section{Рисунок 3. Удельный вес отдельных стран и макрорегионов в общей численности русского населения ближнего зарубежья РФ (бывших союзных республик СССР), 1989-2018/2019 гг., \%}

Источник: Составлено по (Всесоюзная перепись... 1989); Population statistics of Eastern Europe and the former USSR. URL: http://pop-stat.mashke.org (дата обращения 17.03.2020); данным национальных переписей и расчетам автора.

Примечание: Для Молдавии данные за 1999-2019 г2. учитывают русских Приднестровья.

За три постсоветских десятилетия максимально сократилось русское население Закавказья, причем основная часть данного процесса «уложилась» уже в 1990-е годы. К началу XXI века в макрорегионе осталось 250 тыс. русских - в 3,1 раза меньше, чем в 1989 г. (785 тыс.). Но ускоренная депопуляция большинства местных русских общин продолжилась и в 2000-2010-е годы. К настоящему времени в Закавказье может оставаться порядка 120-130 тыс. русского населения. Около половины из них сосредоточено в Баку. Из других крупных территориальных средоточий русских можно выделить Тбилиси (10-12 тыс.) и Абхазию (20-21 тыс. ${ }^{14}$. Таким образом, в настоящее время самая значительная часть русских макрорегиона - это жители двух столичных центров и одного сопредельного России, частично признанного государства.

В Центральной Азии первым из постсоветских государств практически полностью утратил свое русское население Таджикистан: за 1989-2000 гг. его русская община

\footnotetext{
${ }^{14}$ Все остальные центры/территории существенно уступали перечисленным. Из городских общин можно выделить русских Еревана (4-4,5 тыс.), Сумгаита (1,5-1,7 тыс.), Рустави (1,0-1,2 тыс.). Population statistics of Eastern Europe and the former USSR. URL: http://pop-stat.mashke.org (дата обращения 17.03.2020).
} 
сократилась с 388 до 68 тыс. человек. Порядка 1/5 и 1/3 русских от уровня конца 1980-х годов к настоящему времени остается соответственно в Туркмении и Узбекистане. Лучше сохранилась русская община Киргизии, но и она в 1990-2010-е годы сократилась в 2,6 раза. В конце 2010-х годов общая численность русских Средней Азии составляла порядка 0,94-1,0 млн человек, около половины из которых приходилось на две столицы Ташкент (300-350 тыс.) и Бишкек (около 170 тыс.) (Федорко, Курбанов 2018: 44).

Численность русских Казахстана сократилась в постсоветский период более чем на 2,5 млн человек. Но в процентном отношении эта убыль составила только 43-44\%, что было одним из наиболее низких показателей на всем постсоветском пространстве. Данное обстоятельство позволило русской общине страны существенно нарастить свою долю в структуре русского населения всего ближнего зарубежья (за 1990-2010-е годы она выросла с 24,6 до 30,5-32,9\%). Вторая столица Казахстана Алма-Ата является крупнейшим центром русского населения ближнего зарубежья (468 тыс. в 2019 г.). В первой десятке городов Казахстана находятся также Караганда (203 тыс.) и Усть-Каменогорск (183 тыс.).

Достаточно хорошо, по сравнению с другими макрорегионами ближнего зарубежья, сохранилось и русское население Балтии, притом что его динамика существенно различалась по отдельным странам. Темпы убыли русских в Литве были сопоставимы с показателями среднеазиатских государств (к концу 2010-х годов в ней сохранилось 35-38\% русского населения от уровня 1989 г.), а русская община Эстонии демонстрировала максимальную устойчивость во всей группе постсоветских стран ${ }^{15}$. В настоящее время в странах Балтии остается порядка 940-950 тыс. русских, на 82-83\% меньше, чем в конце советского периода.

Существенные различия в темпах убыли сказались на общем соотношении численности русского населения различных макрорегионов. Если значительный масштаб русских общин Украины и Казахстана позволяет этим странам оставаться основными средоточиями русских в пределах ближнего зарубежья России, то изменилось соотношение общин других макрорегионов. Русские Балтии, в конце 1980-х годов удельно уступавшие русскому населению Средней Азии почти в 2 раза (6,8 и 13\% соответственно), к концу 2010-х годов практически сравнялись с ним (8,1-8,7 и 8,6-8,7\%), параллельно обойдя по размеру русские общины Белоруссии и Молдавии. Существенно сократилась доля русских Закавказья, на которых в настоящее время приходится только 1,2\% русского населения ближнего зарубежья. На рубеже 1980-х-1990-х годов этот показатель составлял около $3 \%{ }^{16}$.

\footnotetext{
15 За исключением непризнанной республики Приднестровья.

16 Заметим при этом, что в 1959 г. на Закавказье приходилось 5,9\% русского населения союзных республик СССР. Таким образом, процесс оттока русских из данного макрорегиона начался задолго до распада Советского Союза.
} 


\section{ПОЛОВОЗРАСТНАЯ СТРУКТУРА РУССКОГО НАСЕЛЕНИЯ}

Наряду с демографической убылью для русских ближнего зарубежья в постсоветский период была характерна ощутимая трансформация гендерного баланса и возрастной структуры. Активный миграционный отток не только сокращал русские общины, но, в первую очередь, «вымывал» молодежь и людей среднего трудоактивного возраста. В результате самыми «старыми», как правило, оказывались общины, понесшие в постсоветский период максимальные миграционные потери. Но смещение возрастной структуры в сторону старших генераций негативно сказывалось и на естественновоспроизводственных показателях. Причем центральную роль в повышении естественной убыли играла низкая рождаемость (смертность, как правило, соответствовала российскому показателю).

Медианный возраст русских в большинстве стран ближнего зарубежья уже к началу XXI века составлял 40-42 года, а к настоящему времени с большой вероятностью вырос еще на 2-3 года. В ряде постсоветских государств (в том числе в Латвии, Литве, Молдавии) в середине - второй половине 2010-х годов он находился в диапазоне 46-49 лет. Сохранение данного тренда уже в среднесрочной перспективе способно привести к росту медианного возраста русских в этих странах до 50-55 лет, вследствие чего темпы естественной и общей демографической убыли русских начнут ощутимо ускоряться. Следует, однако, учесть, что повышение медианного возраста русских происходило и в самой России, где он в настоящее время также приблизился к 40 годам, незначительно отличаясь от этого показателя у русского населения Казахстана, Киргизии, Украины, Белоруссии.

Нарушалась в постсоветский период и гендерная структура русских общин ближнего зарубежья. Ощутимая ее разбалансировка была связана с нарастающим перевесом женщин, что в значительной степени объяснялось более активным оттоком мужского населения. Следует учесть и то, что практически во всех странах постсоветского пространства русские женщины значительно чаще мужчин состояли в браках с представителями титульных народов, что также усиливало гендерную диспропорцию в миграционном оттоке русских.

В русской общине Азербайджана уже в 1999 г. на 100 женщин приходилось

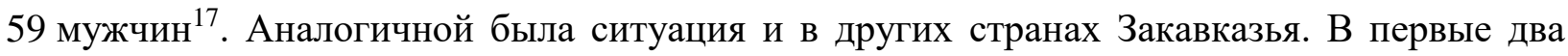
десятилетия XXI века эта гендерная диспропорция еще более усилилась. В остальных макрорегионах ближнего зарубежья данный перекос был не столь значительным. Тем не менее в 2009-2015 гг. в русских общинах Киргизии и Молдавии на 100 женщин приходилось 77-79 мужчин, в Казахстане и Эстонии $-81-82^{18}$.

Нарастающая феминизация значительного числа русских общин ближнего зарубежья негативно сказывалась на их естественной динамике. Дефицит мужчин оборачивался ростом межнациональной брачности русских женщин (в том числе с

\footnotetext{
${ }^{17}$ Юнусов А.С. (2003). Этнические и миграционные процессы в постсоветском Азербайджане. URL: http://chairs.stavsu.ru/geo/Conference/c1-67.htm

18 По данным национальных переписей этих стран.
} 
представителями титульных наций) и усилением ассимиляционного процесса (Бузаев 2016; Остапенко, Субботина 2011: 65).

\section{ФОРМА РАССЕЛЕНИЯ}

Как уже отмечалась, убыль русских в пределах ближнего зарубежья была повсеместной. Но происходили определенные сдвиги и в соотношении различных форм расселения. В советский период русское население большинства союзных республик отличалось повышенным уровнем урбанизированности. В 1989 г. в пяти из них доля горожан у местных русских составляла 92-97\%, в семи - 85-90\%. Только в Казахстане и Киргизии этот уровень был существенно ниже (соответственно 77 и 69,9\%) (Всесоюзная перепись... 1989).

В постсоветский период из 11 стран, по которым имелась соответствующая информация, удельный вес горожан у русского населения вырос только в Азербайджане, не изменился в Таджикистане и на Украине, понизился в 8 странах, в трех - весьма существенно (в Армении, Латвии, Молдавии; рисунок 4). В целом сельское русское население ближнего зарубежья, как правило, демонстрировало более высокую степень укорененности, чем городское.

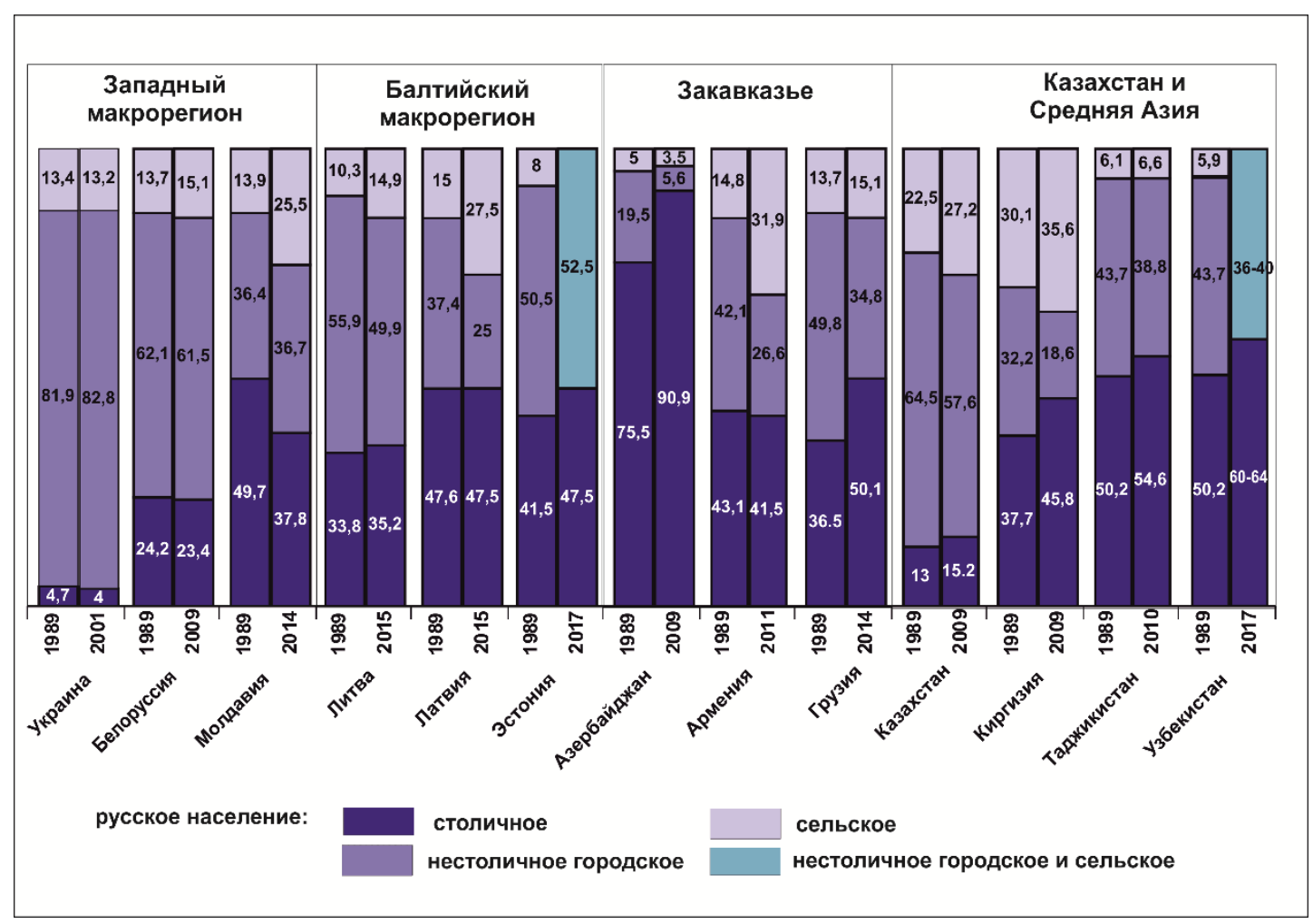

Рисунок 4. Доля различных уровней системы расселения в размещении русского населения стран ближнего зарубежья (союзных республик СССР), \%

Источник: Составлено по (Всесоюзная перепись... 1989); Population statistics of Eastern Europe and the former USSR. URL: http://pop-stat.mashke.org (дата обращения 17.03.2020); данным национальных переписей и расчетам автора. 
А у русских горожан заметно изменилось соотношение между столичным и остальным населением. В шести из тринадцати стран ближнего зарубежья доля русских, сосредоточенных в столицах, выросла (особенно ощутимо в Грузии, Азербайджане, Узбекистане), в четырех - почти не изменилась. При этом удельный вес «нестоличных» русских горожан сократился в восьми из одиннадцати стран. Иными словами, региональные городские сети теряли свое русское население ускоренным темпом, поскольку, помимо оттока в Россию и дальнее зарубежье, часть их русских жителей перебиралась в столичные центры. Таким образом, происходила определенная «поляризация» системы расселения русских, которые концентрировались в столицах и в сельской местности. Но не следует забывать, что данные сдвиги задавались различными темпами убыли и в любом случае были связаны с нарастающей фрагментацией системы расселения, постепенной территориальной анклавизацией русского населения.

В Средней Азии русские почти полностью оставили сельскую местность. Даже в Киргизии, сохранившей более 120 тыс. человек сельского русского населения, оно практически полностью сосредоточено в окрестностях столичного Бишкека (Чуйская область) и отчасти в Иссык-Кульской области. В Узбекистане оно в значительной степени ограничивается сельскими окрестностями Ташкента и ряда областных центров.

Минимальное число русских - сельских жителей сохранилось и в Закавказье, притом что удельный вес их в структуре русских общин менялся разнонаправлено (сократился в Грузии, не изменился в Азербайджане, вырос в Армении). Но во всех трех государствах многократно увеличилось число поселений без русских жителей. А эпицентрами русского этнического присутствия в сельской местности Закавказья оставались редкие старообрядческие села (провинция Лори в Армении, Исмаилы в Азербайджане).

Ощутимо сократилась география сельских русских и в двух других макрорегионах ближнего зарубежья, хотя здесь их система расселения, как правило, оставалась более широкой (за исключением Молдавии и Литвы). Однако самым значительным массивом русского сельского населения располагает Казахстан, на который приходится до половины его численности во всем ближнем зарубежье (940-950 тыс. из 1,94-1,95 млн человек). Порядка 500-570 тыс. сельских русских проживает на Украине (в том числе 100-120 тыс. в республиках Донбасса), более 130 тыс. - в Латвии и 90-95 тыс. - в Белоруссии.

\section{Выводы}

В 1990-2010-е гг. русское население ближнего зарубежья сократилось с 25,3 до 10,7-11,7 млн человек. Наиболее интенсивно данный процесс шел в первое постсоветское десятилетие. Сокращение было повсеместным, захватывая все уровни системы расселения (от столиц до сельской периферии). Русские почти полностью покинули государства постсоветского Закавказья, а также Таджикистан. Существенными оказались их демографические потери и в остальных странах постсоветского пространства. Только в трех государствах (Эстония, Латвия и Казахстан) число русских в настоящее время составляет больше 50\% от показателя 1989 г. 
Существенно деформировалась половозрастная структура русских общин. Практически во всех фиксируется ощутимый перевес женщин, в отдельных странах уже почти двукратный (55-60 мужчин на 100 женщин). Медианный возраст русского населения во всех странах ближнего зарубежья превышает 40 лет, а почти в половине находится в диапазоне 45-50 лет, что становится одной из причин повышенного уровня его естественной убыли (8-10\%о в год и более).

Соотношение различных факторов количественной убыли различалось по периодам и макрорегионам постсоветского пространства. Для первой половины - середины 1990-х годов максимальные потери практически всех русских общин связаны с миграционным оттоком в Россию. В дальнейшем общий тренд сменяется множеством тенденций, характерных для разных стран. В западном макрорегионе (Украина, Белоруссия, Молдавия) центральную роль начинает играть смена идентичности частью русско-титульных биэтнофоров, ассимиляционные процессы, связанные с ростом межнациональной брачности русского населения и выбором титульной национальности смешанным потомством таких семей. В Балтийском регионе (для Литвы и Латвии) также характерна определенная активизация ассимиляции, но основной причиной количественного сокращения с начала XXI века становится отток русских в дальнее зарубежье. В Закавказье и Центральной Азии на протяжении всего постсоветского периода ведущая роль в демографической убыли русских принадлежала миграции в Россию.

Уровень урбанизированности русского населения в большинстве стран ближнего зарубежья в 1990-2010-е годы снизился за счет опережающей убыли нестоличных горожан. Столичные общины и сельское русское население демонстрировали лучшую сохранность, что способствовало определенной пространственной поляризация системы расселения, концентрации русских на ее верхнем и нижнем этажах. Впрочем, значительная часть сельских территорий, сохранявших русское население, также тяготела к столицам и другим крупным центрам.

Изменилось удельное соотношение русских общин отдельных стран и макрорегионов. В настоящее время численность русских Украины (без народных республик Донбасса) и Казахстана уже является сопоставимой. В среднесрочной перспективе (2030-2035 гг.) именно Казахстан с большой вероятностью станет крупнейшим средоточием русского населения в ближнем зарубежье, а страны Балтии по данному показателю обойдут Среднюю Азию.

Более высокой демографической устойчивостью в 2000-2010-е годы отличаются русские общины непризнанных (частично признанных) государств, возникших на постсоветском пространстве. После приобретения ими фактической независимости темпы сокращения местного русского населения существенно снижались и были, в первую очередь, связаны с естественной убылью. В настоящее время на данную группу «политий» приходится уже порядка 12-13\% русских всего ближнего зарубежья. И этот показатель с большой вероятностью продолжит свой рост в будущем.

В целом доля русских постсоветского пространства, сосредоточенных в самой России, неуклонно растет, а удельный вес русских общин всего ближнего зарубежья сокращается. За 1990-2010-е годы он упал в 2 раза (с 17,4 до 8,5-9\%), что является 
результирующей всего комплекса процессов: естественной убыли русского населения, его миграции в Россию и дальнее зарубежье, ассимиляции со стороны титульных народов. Темпы и абсолютные масштабы абсолютного и относительного сокращения русских общин постепенно снижаются. Но сам тренд остается устойчивым на протяжении всего постсоветского периода.

\section{ЛИТЕРАТУРА}

Алейников М.В., Боровиков И.В. (2013). Русское население Казахстана: социальнодемографические трансформации (90-е гг. ХХ в.). Мир Евразии, 2, $2-8$.

Арефьев А.Л. (2012). Русский язык на рубеже XX-XXI веков. М.: Центр социального прогнозирования.

Бузаев В. (2016). Правовое и фактическое положение русскоговорящего меньшинства в Латвии. Рига.

Волков В.В. (2013). Демография русского населения Латвии в XX - XXI вв. Этническая политика в странах Балтии (с. 177-196). М.: Наука.

Всесоюзная перепись населения 1989 года (1989). Демоскоn Weekly. URL: http://www.demoscope.ru/weekly/ssp/resp_nac_89.php

Жуков С.В., Резникова О.В. (2001). Центральная Азия в социально-экономических структурах современного мира. М: Московский общественный научный фонд.

Кабузан В.М. (1996). Русские в мире. Спб: Блиц.

Манаков А.Г. (2020). Территориальные различия в доле русских в постсоветских странах Восточной Европы и Балтии. Известия Академии Наук. Серия географическая, 2, 179190. DOI: $10.31857 / \mathrm{S} 2587556620020090$

Манаков А.Г., Чученкова О.А. (2016). Изменение численности и этнической структуры населения Псково-Балтийского региона с 1897 по 2015 гг. Вестник Псковского государственного университета, Серия «Естественные и физико-математические науки», 8, 77-88.

Марцинкявичус А. (2013). Русские в независимой и советской Литве: демография, социальное положение, идентичность. В Этническая политика в странах Балтии (с. 197-218). М.: Наука.

Митрофанова И.В., Сущий С.Я. (2017). Русские на Украине: геодемографические итоги постсоветского периода и среднесрочные перспективы. Социологические исследования, $8,46-59$.

Мосаки Н.3. (2018). Этническая картина Грузии по результатам переписи 2014 г. Этнографическое обозрение, 1, 104-120. DOI: 10.7868/S086954151801008

Население СССР (1989). М.: Финансы и статистика.

Никифоров И.В., Полещук В.В. (2013). Демография русского населения Эстонии в XX веке. В Этническая политика в странах Балтии (с. 155-176). М.: Наука.

Остапенко Л.В., Субботина И.А. (2011). Русские в Молдавии: социально-демографические трансформации. Социологические исследования, 5, 61-71.

Перепись населения Молдовы 2014 (2014). URL:

https://recensamint.statistica.md/ru/dissemination/person (данные загружены 12.04.2020). 
Романцов В.О. (2008). Населення України і його рідна мова за часів радянськой влади та незалежності (XX - початок XXI століття). Киев: Изд-во им. О. Телигы.

Рыбаковский Л.Л. (1996). Россия и новое зарубежье: миграционный обмен и его влияние на демографическую динамику. М.: ИСПИ РАН.

Савоскул С.С. (2001). Русские нового зарубежья: Выбор судьбы. М.: Наука.

Статистика Эстонии. База данных (2020). URL: http://andmebaas.stat.ee/ (данные загружены 14.04.2020)

Сущий С.Я. (2016). Этнодемографические аспекты русско-украинского взаимодействия (Украина и Юг России). LAP LAMBERT Academic Publishing.

Сущий С.Я. (2018b). Русские Казахстана - геодемографическая динамика постсоветского периода и перспективы первой половины XXI века. Соџиологические исследования, 8 , 22-37. DOI: $10.31857 / \mathrm{S} 013216250000759-7$

Сущий С.Я. (2018а). Русские в Прибалтике - геодемографические тренды постсоветского периода и перспективы первой половины XXI века. Народонаселение, 21(3), 21-36.

Тишков В.А. (1993). Русские в Средней Азии и Казахстане. В Исследования по прикладной и неотложной этнологии (док. № 51). М.: ИЭАРАН.

Федорко В.Н., Курбанов Ш.Б. (2018). Этногеографическое районирование Узбекистана. Известия географического общества Узбекистана, 54 (Ташкент), 42-53.

Халлик К.С. (2011). Русские в Эстонии. В Русские: этносочиологические исследования (с. 90-119). М.: Наука.

Хоперская Л.Л. (2012). Российские соотечественники в Центральной Азии демографический ресурс, отрезанный ломоть или хранители русского мира? Этнопанорама, 3-4, 5-12.

Цуциев А.А. (2006). Атлас этнополитической истории Кавказа (1774-2004). М.: Европа. 


\title{
THE RUSSIAN POPULATION OF THE NEAR ABROAD: GEODEMOGRAPHIC DYNAMICS OF THE POST-SOVIET PERIOD
}

\section{SERGEY SUSHCHIY}

\begin{abstract}
This article explores the geodemographic dynamics of the Russian population of the near abroad in the postSoviet period. It analyzes the quantitative changes and transformation of its geography, the level of urbanization and the gender and age structure. The study showed that in the post-Soviet period there was a sharp decline in the number of Russians in all neighboring countries. This process was most intensive in the 1990s. The maximum demographic losses during this period were suffered by the Russian population of Transcaucasia and a number of countries in Central Asia. At the beginning of the twenty-first century, the rate and absolute scale of decline are decreasing, but the trend itself remains stable. This is associated with the natural decline of the Russian population, its migration to Russia and foreign countries, and assimilation. The relationship of these factors to the quantitative decline has varied across time and across individual countries. In almost all Russian communities, a significant preponderance of women is recorded. The median age of Russians in all neighboring countries is more than 40 years. The level of urbanization of Russians in most neighboring countries has decreased. Better preserved are the metropolitan and rural Russian populations. The demographic ratio of the Russian communities of individual countries and macroregions has changed. The number of Russians in Kazakhstan and Ukraine (without the people's republics of Donbass) is already comparable, and there are more Russians in the Baltic countries than in Central Asia. Russian communities of unrecognized (partially recognized) states are characterized by increased demographic stability.
\end{abstract}

Key words: neighboring countries, Russian population, geodemographic dynamics, sex and age structure, level of urbanization, migration, assimilation.

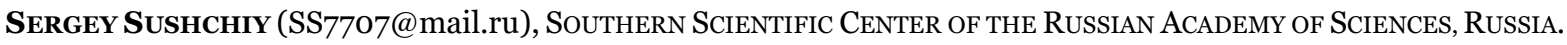

THIS ARTICLE WAS PREPARED AS PART OF THE STATE ASSIGNMENT OF THE SOUTHERn SCIENTIFIC CENTER OF THE RAS, INTERDISCIPLINARY PROJECT NO. O2-20-MD "RUSSIAN PEOPLE IN THE FIRST HALF OF THE XXI CENTURY GEODEMOGRAPHIC REALITIES AND PROSPECTS".
}

DATE RECEIVED: APRIL 2020.

\section{REFERENCES}

Aleinikov M.V., Borovikov I.V. (2013). Russian population of Kazakhstan: socio-demographic transformations (the 90s of the XX century). Mir Evrazii [Eurasia World], 21 (2), 2-8. (In Russ.).

Arefiev A.L. (2012). Russkiy yazyk na rubezhe XX-XXI vekov [Russian language at the turn of the XX-XXI centuries]. Moscow: TSentr sotsial'nogo prognozirovaniya. (In Russ.).

Buzaev V. (2016). Pravovoye i fakticheskoye polozheniye russkogovoryashchego men 'shinstva v Latvii [The legal and actual situation of the Russian-speaking minority in Latvia]. Riga. (In Russ.).

Fedorko V.N., Kurbanov Sh.B. (2018). Etnogeograficheskoye rayonirovaniye Uzbekistana [Ethno-geographical zoning of Uzbekistan]. Izvestiya geograficheskogo obshchestva 
Uzbekistana [News of the Geographical Society of Uzbekistan], 54 (Tashkent), 42-53. (In Russ.)

Kabuzan V.M. (1996). Russkiye v mire [Russians in the world]. St. Petersburg: Blits. (In Russ.).

Khallik K.S. (2011). Russkiye v Estonii [Russians in Estonia]. In Russkiye: etnosotsiologicheskiye issledovaniya [Russians: ethnosociological research] (pp. 90-119). Moscow: Nauka. (In Russ.)

Khoperskaya L.L. (2012). Rossiyskiye sootechestvenniki v TSentral'noy Azii demograficheskiy resurs, otrezannyy lomot' ili khraniteli russkogo mira? [Are Russian compatriots in Central Asia a demographic resource, a slice cut off or keepers of the Russian world?]. Etnopanorama, 3-4, 5-12. (In Russ.)

Manakov A.G. (2020). Territorial'nyye razlichiya v dole russkikh v postsovetskikh stranakh Vostochnoy Evropy i Baltii [Territorial differences in the share of Russians in the post-Soviet countries of Eastern Europe and the Baltic]. Izvestiya Akademii Nauk. Seriya geograficheskaya, 2, 179-190. (In Russ.). DOI: 10.31857/S2587556620020090

Manakov A.G., Chuchenkova O.A. (2016). Izmeneniye chislennosti i etnicheskoy struktury naseleniya Pskovo-Baltiyskogo regiona s 1897 po $2015 \mathrm{gg}$. [Change in the number and ethnic structure of the population of the Pskov-Baltic region from 1897 to 2015]. Vestnik Pskovskogo gosudarstvennogo universiteta, Seriya «Estestvennyye i fiziko-matematicheskiye nauki», 8, 77-88. (In Russ.).

Martsinkyavichus A. (2013). Russkiye v nezavisimoy i sovetskoy Litve: demografiya, sotsial'noye polozheniye, identichnost' [Russians in independent and Soviet Lithuania: demography, social status, identity]. In Etnicheskaya politika $v$ stranakh Baltii [Ethnic policy in the Baltic countries] (pp. 197-218). Moscow: Nauka. (In Russ.).

Mitrofanova I.V., Sushchiy S.Ya. (2017). Russkiye na Ukraine: geodemograficheskiye itogi postsovetskogo perioda i srednesrochnyye perspektivy. Sotsiologicheskiye issledovaniya, 8 , 46-59. (In Russ.).

Mozaki N.Z. (2018). Etnicheskaya kartina Gruzii po rezul'tatam perepisi 2014 g. [Ethnic picture of Georgia according to the results of the 2014 census]. Etnograficheskoye obozreniye, 1, 104-120. (In Russ.).

Naseleniye SSSR [The population of the USSR] (1989). Moscow: Finansy i statistika. (In Russ.).

Nikiforov I.V., Poleschuk V.V. (2013). Demografiya russkogo naseleniya Estonii v XX veke [Demography of the Russian population of Estonia in the twentieth century]. In Etnicheskaya politika v stranakh Baltii [Ethnic policy in the Baltic countries] (pp. 155-176). Moscow: Nauka. (In Russ.)

Ostapenko L.V., Subbotina I.A. (2011). Russkiye v Moldavii: sotsial'no-demograficheskiye transformatsii. Sotsiologicheskiye issledovaniya, (5), 61-71. (In Russ.).

Perepis' naseleniya Moldovy 2014 [Census of Moldova 2014] (2014). Retrieved from https://recensamint.statistica.md/en/dissemination/person (data downloaded on 12.04.2020).

Romantsov V.O. (2008). Naselennya Ukraïni i yogo ridna mova za chasiv radyans'koï vladi ta nezalezhnosti (XX-pochatok XXI stolittya) [The population of Ukraine and its native language during the days of Soviet power and independence: $\mathrm{XX}$ - the beginning of the XXI century]. Kiev: Izdatel'stvo im. O. Teligy. (In Russ.).

Rybakovsky L.L. (1996). Rossiya i novoye zarubezh'ye: migratsionnyy obmen i ego vliyaniye na demograficheskuyu dinamiku [Russia and the New Abroad: Migration Exchange and its Impact on Demographic Dynamics]. Moscow: ISPI RAN. (In Russ.). 
Savoskul S.S. (2001). Russkiye novogo zarubezh'ya: Vybor sud'by [Russian new abroad: the choice of fate]. Moscow: Nauka. (In Russ.).

Statistika Estonii. Baza dannykh [Statistics of Estonia. Database] (2020). Retrieved from http: //andmebaas.stat.ee/ (data downloaded on 04.04.2020).

Sushchiy S.YA. (2016). Etnodemograficheskiye aspekty russko-ukrainskogo vzaimodeystviya (Ukraina i YUg Rossii) [Ethnodemographic aspects of Russian-Ukrainian interaction (Ukraine and the South of Russia)]. LAP LAMBERT Academic Publishing.

Sushchiy S.YA. (2018a). Russkiye v Pribaltike - geodemograficheskiye trendy postsovetskogo perioda i perspektivy pervoy poloviny XXI veka [Russians in the Baltics - geodemographic trends of the post-Soviet period and prospects for rst half of the XXIst century]. Narodonaseleniye, 21(3), 21-36. DOI: 10.26653/1561-7785-2018-21-3-02. (In Russ.)

Sushchiy S.YA. (2018b). Russkiye Kazakhstana - geodemograficheskaya dinamika postsovetskogo perioda i perspektivy pervoy poloviny XXI veka. Sotsiologicheskiye issledovaniya, 8, 22-37. (In Russ.) DOI: 10.31857/S013216250000759-7

Tishkov V.A. (1993). Russkiye v Sredney Azii i Kazakhstane [Russians in Central Asia and Kazakhstan]. In Issledovaniya po prikladnoy i neotlozhnoy etnologii [Studies in applied and urgent ethnology] (Doc. no. 51). Moscow: IEARAN. (In Russ.).

Tsutsiev A.A. (2006). Atlas etnopoliticheskoy istorii Kavkaza (1774-2004). [Atlas of the ethnopolitical history of the Caucasus (1774-2004)]. Moscow: Evropa. (In Russ.).

Volkov V.V. (2013). Demografiya russkogo naseleniya Latvii v KHKH - XXI vv. [Demography of the Russian population of Latvia in the XX - XXI centuries]. In Etnicheskaya politika $v$ stranakh Baltii [Ethnic policy in the Baltic countries] (pp. 177-196). Moscow: Nauka. (In Russ.).

Vsesoyuznaya perepis' naseleniya 1989 goda [All-Union Population Census 1989] (1989). Demoscope Weekly. URL: http://www.demoscope.ru/weekly/ssp/resp_nac_89.php (In Russ.).

Zhukov S.V., Reznikova O.V. (2001). TSentral'naya Aziya v sotsial'no-ekonomicheskikh strukturakh sovremennogo mira [Central Asia in the socio-economic structures of the modern world]. Moscow: Moskovskiy obshchestvennyy nauchnyy fond. (In Russ.). 